\title{
URBAN LAYOUT AND ENERGY SAVINGS
}

\author{
Wojciech Skórzewski ${ }^{\bowtie}$ \\ Faculty of Architecture, Poznan University of Technology
}

\begin{abstract}
In the era of climate changes, one of the most important challenges of architectural designing is a reduction of energy consumption in buildings for heating and cooling purposes. A significant component of the energy balance of buildings is passive solar heat gains, the amount of which depends, among other things, on the mutual location of buildings. The article discusses the preliminary research on the possibilities of achieving energy savings of buildings at the stage of urban design in Polish legal and climatic conditions. The study includes the analysis of several variants of the layout of buildings located at the same plot.
\end{abstract}

Key words: urban planning, energy-efficient architecture, insolation, building layout

\section{INTRODUCTION}

The energy consumption becomes a more and more important issue of modern architecture in the era of climate changes. Reducing the energy demand in buildings is an important contribution of architecture to limiting the fossil fuel combustion, and thus helps to improve air quality and to prevent climate changes. A number of fields of science and industry are involved in energy-saving solutions in building construction, including building physics (thermals), building materials technologies, power engineering, renewable energy sources etc. and, obviously, architectural design. Also, urban planning should be mentioned here, of which importance for reducing energy consumption in buildings is the subject of this article.

\section{MAIN SCIENTIFIC PROBLEM}

\section{Origin of the research problem}

Energy consumption in buildings means both electricity (for the purposes of artificial lighting and the functioning of devices) and thermal energy, which this arti- cle is focused on. The thermal energy, defined as both energy used for heating purposes in winter and cooling purposes in summer, is a significant part of energy demand in buildings. In order to reduce it, a number of technical solutions are used, like improving the thermal insulation of the building envelope, efficient mechanical ventilation systems with heat recovery, efficient heat sources using renewable energy and including passive heat sources in the energy balance of the building. Passive heat gains include, among others, gains from solar radiation entering a building interior through the glazed parts of facades. This is the issue that shows the potential of urban planning in designing an energy-efficient development, while today the aspects of energy consumption are still not sufficiently taken into account in the realities of the Polish spatial planning system.

The amount of passive solar heat gains is affected by multiple factors, including technical factors, like: building materials used on building facades, types of glazing used in windows; and geometrical factors, like: distances between buildings, heights of buildings, orientation of facades towards the directions of 
the world, share of glazed parts in the facade area, location and distribution of greenery around buildings.

The impact of these geometrical factors mentioned above is foreseeable at the stage of urban design. Appropriate design of the spatial layout of buildings can, therefore, give some energy savings without the need for other technical solutions that would increase construction costs.

\section{State of the art}

The issue of the impact of a proper location of the building on the energy consumption in buildings appears from the very beginning in the idea of passive buildings, developed by Passivhaus Institut in Darmstadt (Feist, Munzenberg \& Thumulla, 2009). One of the main assumptions of the passive house standard is including passive heat sources in the energy balance of the building, among which solar radiation passing through windows into the building interior plays an important role. The amount of passive solar heat gains depends on the degree of shading windows or other glazed parts of facades and, for this reason, the location of the shading objects (including buildings) in the surroundings becomes important. This makes urbanism one of the significant fields of energy efficiency research.

The issues of the influence of urban planning on energy efficiency have been described in some publications from Poland and abroad. Many authors point to the need to include energy efficiency issues, especially solar energy, in the process of urban designing (Amado \& Poggi, 2012; Sobczyk \& Bracha, 2014). Researchers have been presenting various approaches to the topic. Strømann-Andersen and Sattrup (2011) analysed the impact of the size of urban canyons on access to solar radiation and daylight and thus energy use for heating, cooling and artificial lighting purposes. According to their research conducted in the climate conditions in Copenhagen, Denmark, the impact of distances between buildings on the total energy usage consumption is very significant, reaching up to $+30 \%$ for offices and $+19 \%$ for housing. A comprehensive study on the impact of the environment on the building's energy demand was conducted in Singapore by Wong et al. (2011), analysing a number of different cases of the surrounding of the same building, differing in building height and density, green plot ratio and their combination. A study conducted for Tianjin city in China (Tong et al., 2018) showed the correlation between different urban morphology parameters, like the type of surface, the width of space between buildings etc. with air temperature in the city. Morganti, Salvati, Coch and Cecere (2017) have proposed to use selected urban morphology indicators to evaluate the building layouts in terms of solar energy availability. Amado and Poggi (2014) proposed the methodology using common GIS and CAD software to evaluate the urban morphology impact on the use of solar energy. Problems of energy efficiency and use of solar energy in urban planning appears also in many other publications (Chwieduk, 2006, 2014; van Esch, Looman \& de Bruin-Hordijk, 2012; Stangel, 2013; Sarralde, Quinn, Wiesmann \& Steemers, 2015; Grzymała, 2016; Zhou, Zhuang, Yang, Yu \& Xie, 2017).

\section{MATERIAL AND METHODS}

\section{The aim of the research}

The paper discusses the preliminary research on the possibilities of achieving energy savings in buildings at the stage of urban design in Polish legal and climate conditions. The aim of the research is:

- to check how different building layouts influence the amount of solar energy reaching the facades;

- to check how the relative location of buildings affects the degree of shading of their facades;

- to find the best possible balance between solar gains and losses, taking into consideration the fact, that limiting sun exposure can result in two ways: it can be useful to reduce overheating in summer, but on the other hand, it reduces solar heat gain in winter.

To achieve the aim of the research, it is necessary to make simulations of the distribution of solar radiation on the surfaces of building facades, for a few different variant concepts of the plot development. This allows us to compare the amount of solar energy, which can be used as a passive source of heat, between different variants. 


\section{Research material}

An exemplary quarter of the designed development in Poznan has been taken as a material for research. The considered quarter is located in the neighbourhood of Grunwaldzka and Ułańska streets in Poznań and it is a piece of a larger urban concept composed of residential and office buildings surrounded by historical tenement houses and post-military buildings.

The plot of land with a shape similar to a rectangle and dimensions of approx. $90 \times 145 \mathrm{~m}$ has been selected for the research. The direct surroundings of the given plot are designed as built-up with compact frontage buildings with a height of approx. $17 \mathrm{~m}$ and 5 storeys.

The assumptions for the new-designed development of the plot are the following:

- height of the designed buildings the same as surroundings $-17 \mathrm{~m}, 5$ storeys;

- built-up area of approx. 4,500 $\mathrm{m}^{2}$, which means approx. $22,500 \mathrm{~m}^{2}$ of gross floor area and approx. $15,750 \mathrm{~m}^{2}$ of usable floor area;

- width of buildings of $14 \mathrm{~m}$, which ensures the possibility of locating apartments in a two-bay layout;

- meeting sunlight requirements for each apartment in the amount of at least $3 \mathrm{~h}$ on equinox days $(21 \mathrm{st}$ March and 23rd September), according to the Polish regulation on technical conditions of the buildings and their location (Regulation of the Minister of Infrastructure of 12 April 2002 on technical specifications for buildings and their location).

Taking above-mentioned assumptions into account, four variant land development concepts have been prepared, differing in the layout of buildings, but with a comparable built-up area and gross floor area and the same height. The concepts are the following:

- variant 1: perimeter frontage buildings along the streets, around the quarter, with one large rectangular courtyard inside;

- variant 2: parallel buildings along the east-west axis;

- variant 3: parallel buildings along the north-south axis;

- variant 4: comb-shaped layout of buildings with the courtyards open to the south side of the plot.

\section{Research methods and tools}

Amount of passive solar heat gains can be calculated using the following formula (Feist et al., 2009):

$$
Q_{s}=r \cdot g \cdot A_{g} \cdot G\left[\mathrm{kWh} \cdot \text { year }^{-1}\right]
$$

where:

$Q_{s}$ - total amount of passive solar gains;

$r$ - reduction coefficient, including the solar incidence angle, shading and dirt;

$g-$ total solar energy transmittance of the glazing (g-factor);

$A_{g}$ - glazing area;

$G$ - total solar radiation during the heating season.

As we can see, the amount of passive solar heat gains depends on a few factors. Total solar radiation $(G)$ is constant, but the designer can influence the rest of them:

- g-factor ( $g$, total solar energy transmittance), which depends on the type of glazing;

- glazing area $\left(A_{g}\right)$, that depends on the amount and dimensions of windows or glazed curtain walls;

- reduction coefficient $(r)$, that depends, inter alia, on the urban layout, which affects the degree of shading of facades.

The third of the factors mentioned above is the focus of the research described in this article. The reduction factor is strongly connected with shading the facades of the building, which depends on various features of the surroundings, like:

- orientation of facades towards the directions of the world;

- distances to the other buildings in the neighbourhood;

- heights of buildings in the neighbourhood;

- building materials used on building facades in surroundings;

- location and distribution of greenery around buildings.

The majority of the factors mentioned above are connected with the geometry of the urban layout, so they are foreseeable at the stage of urban design. Appropriate design of the spatial layout of buildings can, therefore, give some energy savings without the need 
for other technical solutions that would increase construction costs.

To calculate the amount of solar radiation on the facades for each variant concept, there has been a need to create a model of designed development with surroundings, prepared in $3 \mathrm{~d}$ modelling software - Sketchup, which is a commonly used tool among architects. The model has been created in a simplified form, with facades represented as flat surfaces, without modelling any architectural detail or windows. The glazing ratio of $1 / 8$ of the usable floor area, as a minimum required value for housing, has been assumed. Such an approach should is aimed at excluding the impact of individual architectural solutions on research results, and taking into account only factors related to the location of buildings, which is the subject of the research. This method has been chosen in order to exclude the impact of any other (not connected with the urban layout) factors on the energy performance of buildings.

The tool used for the calculation of solar radiation reaching building facades has been DL-Light software, which is an extension to Sketchup. The calculations have been carried out using the following settings of the program:

- calculation with interreflections;

- material of the facades: light concrete, reflectance factor: 0.416465 , transmittance factor: 0.0 ;

- ground albedo: $20 \%$;

- degree of detail: approx. 1 sensor per $10 \mathrm{~m}^{2}$.

Because the climate data for Poznan are not available in the DL-Light software, the research has been carried out using climatic data of Berlin - that is the closest location to Poznan among those available in the DL-Light software, located at the same latitude. For each of the four variant concepts, the calculations have been carried out for two periods of the year: summer (from 21st June to 22nd September, 93 days) and winter (from 22nd December to 20th March, 89 days). The results of calculations have been presented as diagrams of the average solar radiation distribution on the facades.

\section{RESULTS}

The results of calculations have been presented as diagrams of the average solar radiation distribution on the facades in two periods: winter and summer (Figs. 1-4). We can observe the differences of the impact of shading on the amount of solar energy depending on the facade orientation towards the direction of the world. On the east and west facades, the reduction of radiation due to the shading is more significant in summer than in winter (which is beneficial for the energy balance of the building), while on the south facades, this is inverse - reduction is greater in winter than in summer. Therefore, optimal distances between buildings in terms of access to solar radiation are various depending on the orientation of the facade.

The summary results of the solar radiation on the facades for all four variants are presented below on the charts. In the first two charts (Fig. 5), we can see a comparison of the average daily amount of solar energy per $1 \mathrm{~m}^{2}$ of the facade (on the left) and the same

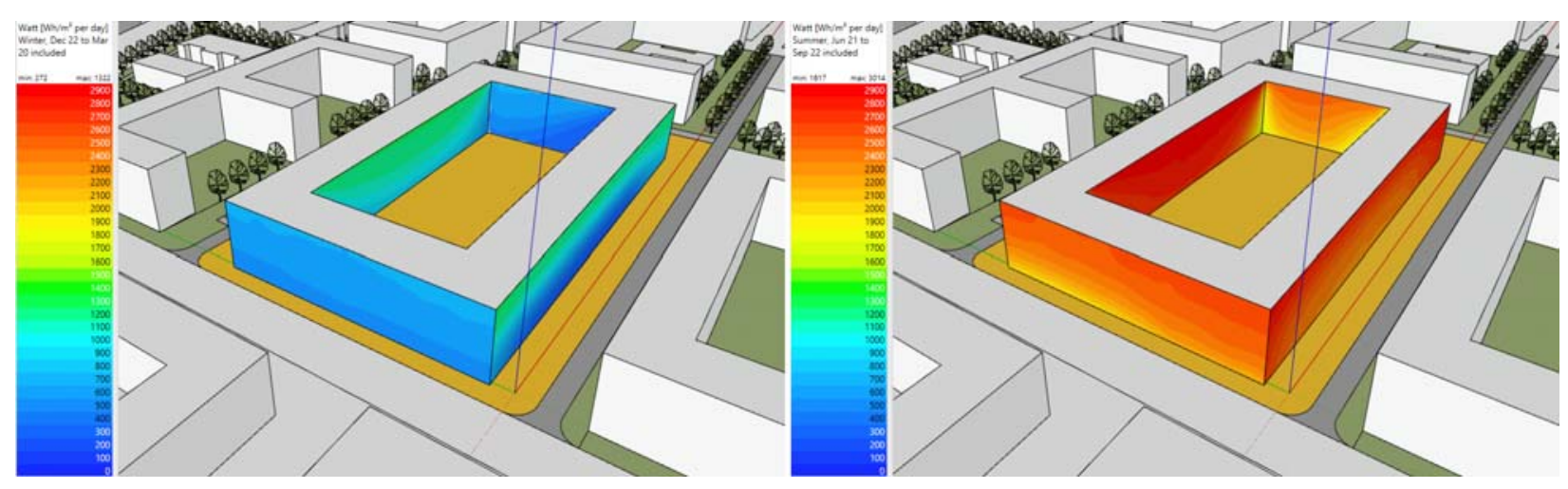

Fig. 1. Distribution of the solar radiation $\left[\mathrm{Wh} \cdot \mathrm{m}^{-2} \cdot \mathrm{day}^{-1}\right]$ on building facades - variant 1 : left - winter, right - summer (Sketchup + DL-Light 


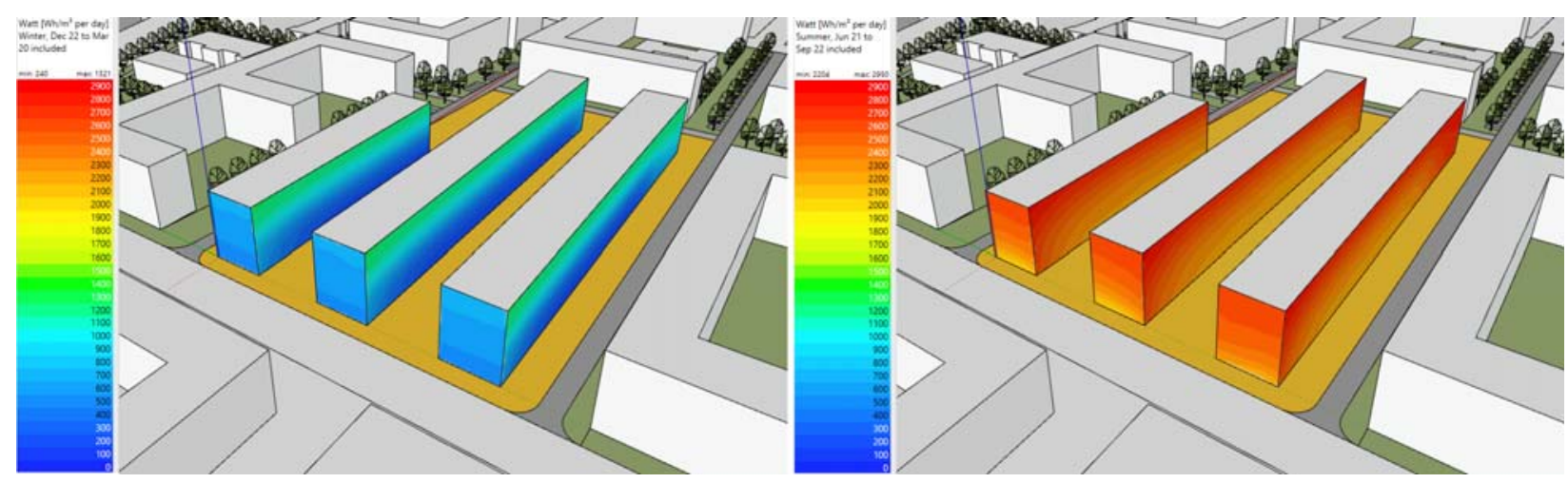

Fig. 2. Distribution of the solar radiation $\left[\mathrm{Wh} \cdot \mathrm{m}^{-2} \cdot \mathrm{day}^{-1}\right]$ on building facades - variant 2 : left - winter, right - summer (Sketchup + DL-Light)

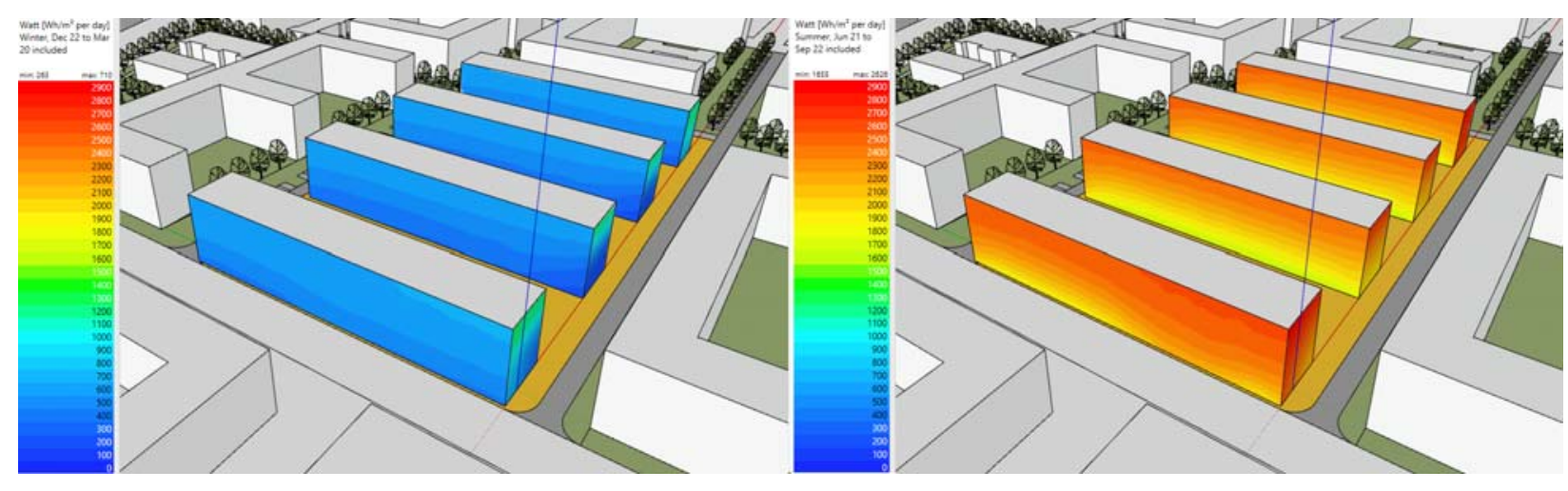

Fig. 3. Distribution of the solar radiation $\left[\mathrm{Wh} \cdot \mathrm{m}^{-2} \cdot \mathrm{day}^{-1}\right]$ on building facades - variant 3 : left - winter, right - summer (Sketchup + DL-Light)

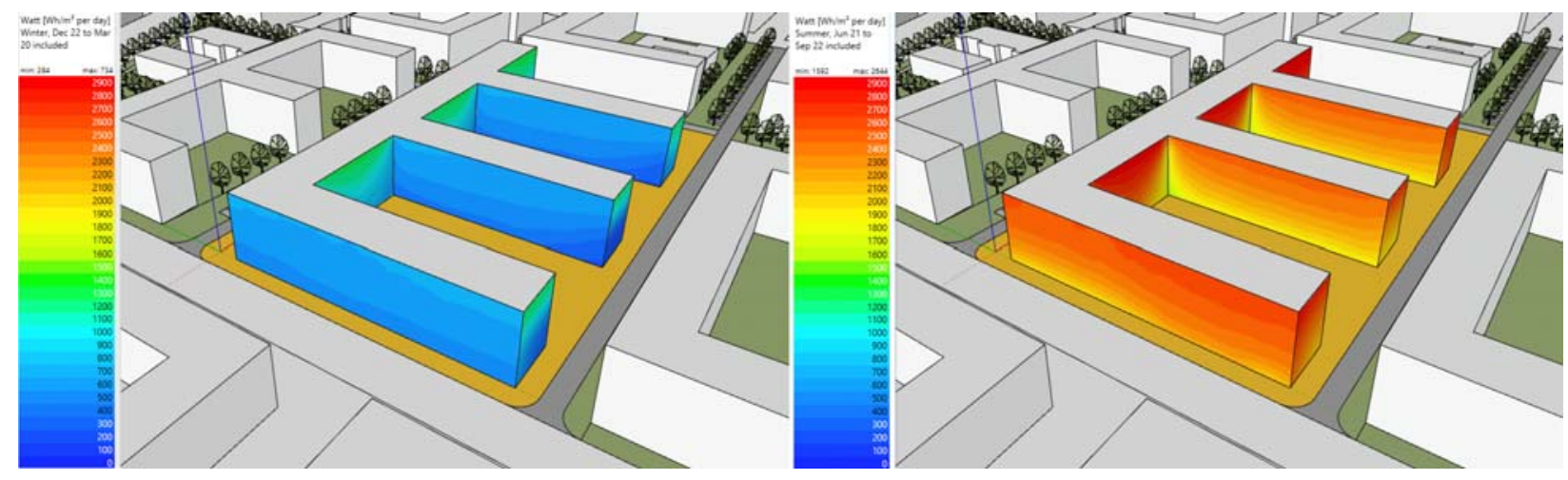

Fig. 4. Distribution of the solar radiation $\left[\mathrm{Wh} \cdot \mathrm{m}^{-2} \cdot \mathrm{day}^{-1}\right]$ on building facades - variant 4 : left - winter, right - summer (Sketchup + DL-Light) 
results in relation to the first variant. As we can see, all three other options are characterized by a decrease in solar heat gains per $1 \mathrm{~m}^{2}$ of the facade area in winter in comparison to variant 1 with perimeter frontage buildings with an inner courtyard. Only in the second variant - parallel buildings along the east-west axis - we can observe adecrease of the average solar radiation in summer, which would help reduce overheating.

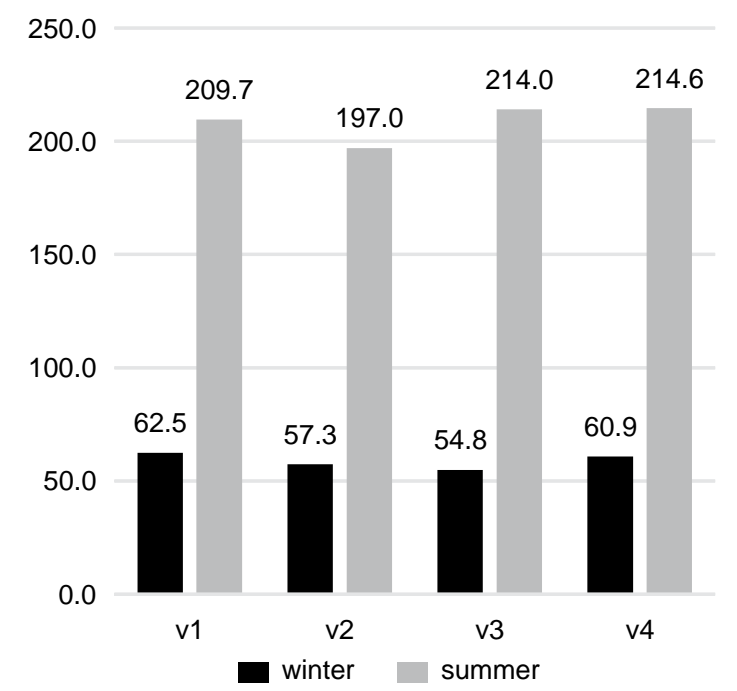

However, if instead of the average radiation per $1 \mathrm{~m}^{2}$ of the facade we take into account the total amount of radiation on the entire surface of the facades (Fig. 6), it will turn out that in all variants $(2-4)$, solar radiation in winter is slightly higher than in the first variant, but also the radiation in the summer increases much more significantly. This applies especially to variant 3 , which is characterized by a much higher level of solar

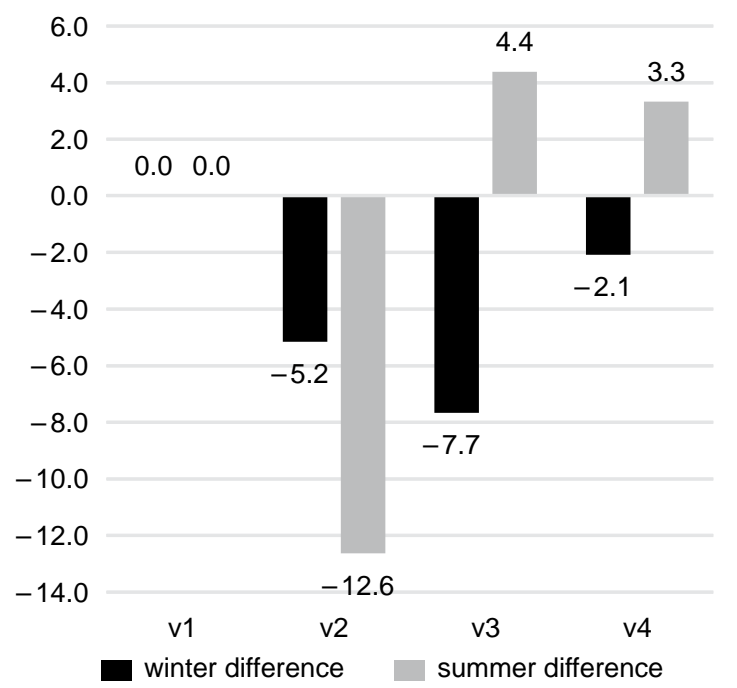

Fig. 5. Average amount of solar radiation $\left[\mathrm{Wh} \cdot \mathrm{m}^{-2} \cdot \mathrm{day}^{-1}\right]$ of the facade surface (left) and its difference in relation to the first variant (right)
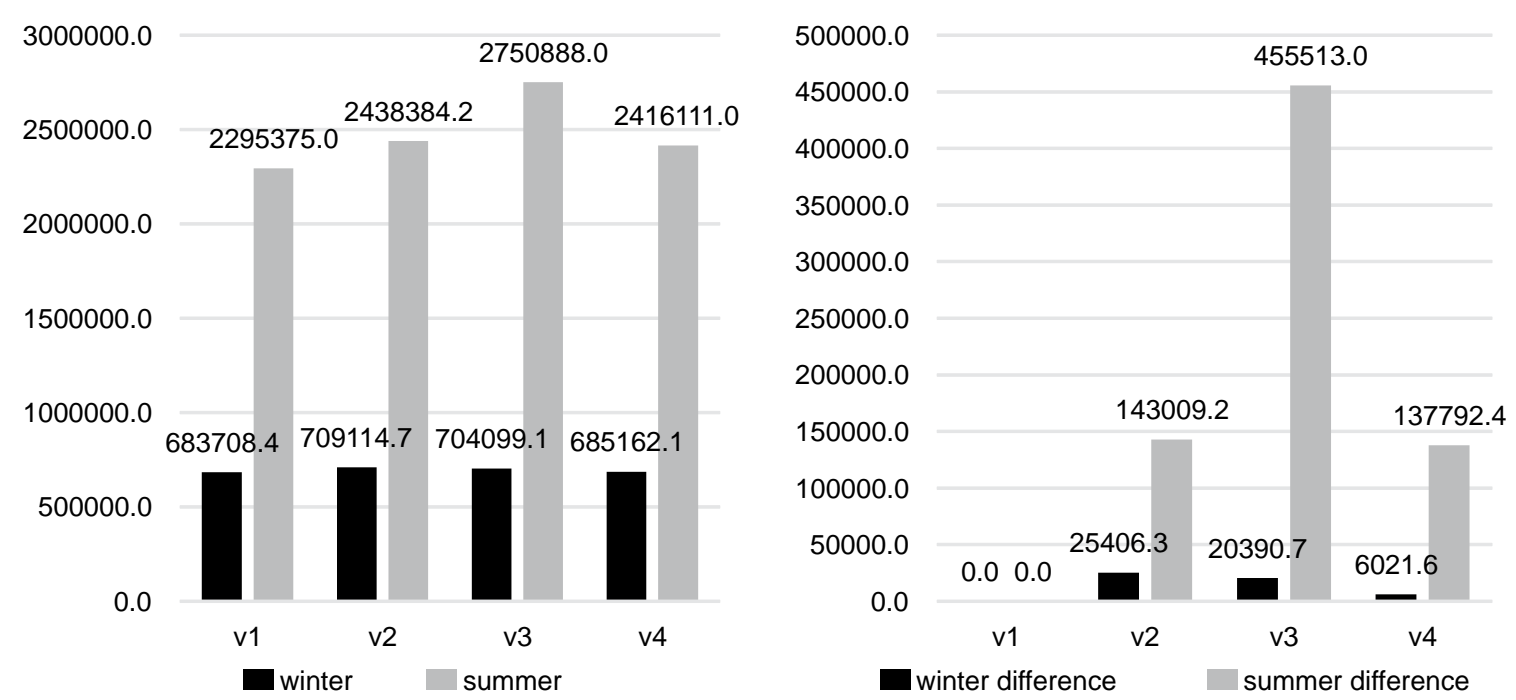

Fig. 6. Total amount of solar radiation $\left[\mathrm{Wh} \cdot \mathrm{day}^{-1}\right]$ on the facades (left) and its difference in relation to the first variant (right) 


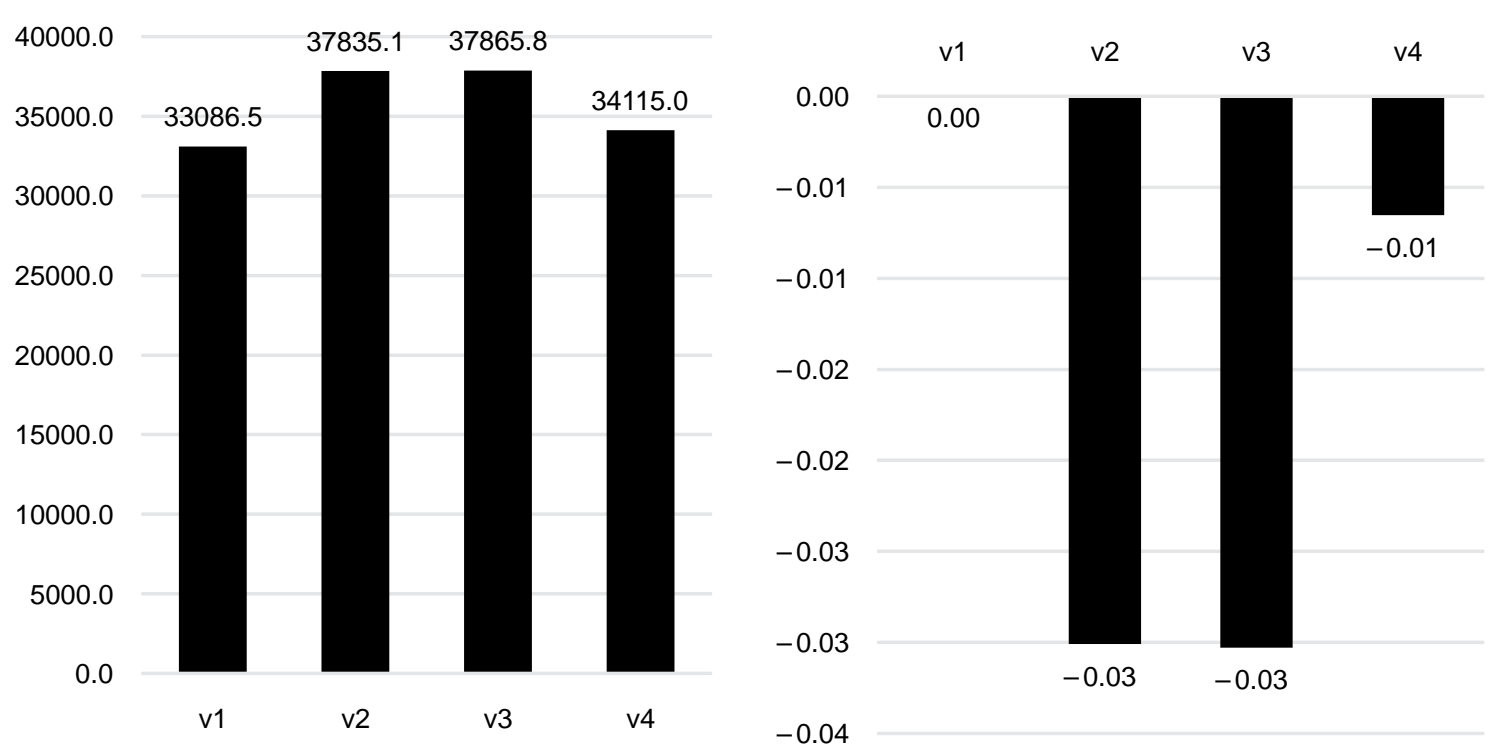

Fig. 7. Total heat transfer $\left[\mathrm{kWh} \cdot \mathrm{a}^{-1}\right]$ through the facades (left) and difference of heat transfer related to usable floor area $\left[\mathrm{kWh} \cdot \mathrm{m}^{-2} \cdot \mathrm{a}^{-1}\right]$ in comparison to the first variant (right)

radiation in summer, which results from a large area of the eastern and western facades, especially exposed to a sunlight from a low angle, which may lead to overheating of the building's interior.

It is also worth noting the amount of heat loss by heat transfer through external walls (Fig. 7) which is closely related to the total facade area. Taking this factor into account, the most advantageous is also variant 1 with frontage buildings.

\section{CONCLUSIONS}

The initial results show that the mutual location of buildings affects the potential amount of passive solar heat gains. Shading the facades by other buildings located in its direct neighbourhood (or other parts of the same building) reduces the amount of solar energy delivered to facades to varying degrees depending on the distance of the shading object from the facade, the orientation of the facade in relation to the directions of the world and the seasons. There are a few regularities, that we can observe:

- the highest risk of overheating is for east and west facade;

- the south facades give the best possibilities to take benefits from passive solar gains in winter; so the most profitable are urban layouts with larger distances between facades located on that direction (Strømann-Andersen \& Sattrup, 2011).

Such a difference between north-south and east-west direction confirms similar observations regarding the impact on irradiation in urban canyon by van Esch et al. (2012).

The research show also, that in case of the same parameters assumed for all facades (regardless of the direction towards the directions of the world), some energy benefits achieved on the selected surfaces of building facades are offset by losses on the others. To improve the energy balance it would be needed to differentiate same facade parameters, like glazing ratio etc. for each direction.

This issue should be continued in future more detailed research, taking into consideration the additional factors, like a different glazing ratio of facades, different types of glazing or different heights of buildings. Another issues to be included in the scope of the research are the solar radiation on roofs (Amado \& Poggi, 2012; Sarralde et al., 2015) and the impact of greenery in front of building facades, which has been already the subject of the author's initial research (Skórzewski, 2019). All these factors mentioned above should be reflected in urban layouts of designed energy-efficient developments. 


\section{REFERENCES}

Amado, M. \& Poggi, F. (2012). Towards Solar Urban Planning: A New Step for Better Energy Performance. Energy Procedia, 30, 1261-1273. doi: 10.1016/ j.egypro.2012.11.139

Amado, M. \& Poggi, F. (2014). Solar Urban Planning: A Parametric Approach. Energy Procedia, 48, 1539 -1548. doi: 10.1016/j.egypro.2014.02.174

Chwieduk, D. (2006). Modelowanie $i$ analiza pozyskiwania oraz konwersji termicznej energii promieniowania słonecznego w budynku. Warszawa: Instytut Podstawowych Problemów Techniki PAN.

Chwieduk, D. (2014). Solar Energy in Buildings: Thermal Balance for Efficient Heating and Cooling. Elsevier.

Esch, M. M. E. van, Looman, R. H. J. \& Bruin-Hordijk, G. J. de (2012). The effects of urban and building design parameters on solar access to the urban canyon and the potential for direct passive solar heating strategies. Energy and Buildings, 47, 189-200. doi: 10.1016/ j.enbuild.2011.11.042

Feist, W., Munzenberg, U. \& Thumulla, J. (2009). Podstawy budownictwa pasywnego. Gdańsk: Polski Instytut $\mathrm{Bu}-$ downictwa Pasywnego.

Grzymała, Z. (2016). Miasta ekologiczne - studia przypadków i perspektywy rozwoju [Eco-cities - case studies and development perspectives]. Research Papers of Wrocław University of Economics, 432, 61-66.

Morganti, M., Salvati, A., Coch, H. \& Cecere, C. (2017). Urban morphology indicators for solar energy analysis. Energy Procedia, 134, 807-814. doi: 10.1016/ j.egypro.2017.09.533

Rozporządzenie Ministra Infrastruktury z dnia 12 kwietnia 2002 r. w sprawie warunków technicznych, jakim powinny odpowiadać budynki i ich usytuowanie. Dz.U. $2002 \mathrm{nr} 75$, poz. 690 [Regulation of the Minister of Infrastructure of 12 April 2002 on technical specifications for buildings and their location. Journal of Laws 2002 No 75, item 690].

Sarralde, J. J., Quinn, D. J., Wiesmann, D. \& Steemers, K. (2015). Solar energy and urban morphology: Scenarios for increasing the renewable energy potential of neighbourhoods in London. Renewable Energy, 73, 10-17. doi: 10.1016/j.renene.2014.06.028

Skórzewski, W. (2019). Potential of using greenery to reduce overheating of buildings in Polish climate conditions. Scientific Review Engineering and Environmental Sciences, 28 (4), 619-631. doi: 10.22630/ PNIKS.2019.28.4.56

Sobczyk, W. i Bracha, K. (2014). Słoneczne budownictwo pasywne jako alternatywa dla zużycia surowców kopalnych. Edukacja - Technika - Informatyka, 1 (5), 335-340.

Stangel, M. (2013). Ksztaltowanie wspótczesnych obszarów miejskich $w$ kontekście zrównoważonego rozwoju. Gliwice: Wydawnictwo Politechniki Śląskiej.

Strømann-Andersen, J. \& Sattrup, P. A. (2011). The urban canyon and building energy use: Urban density versus daylight and passive solar gains. Energy and Buildings, 43 (8), 2011-2020. doi: 10.1016/j.enbuild.2011.04.007

Tong, S., Wong, N. H., Jusuf, S. K., Tan, C. L., Wong, H. F., Ignatius, M. \& Tan, E. (2018). Study on correlation between air temperature and urban morphology parameters in built environment in northern China. Building and Environment, 127, 239-249. doi: 10.1016/ j.buildenv.2017.11.013

Wong, N. H., Jusuf, S. K., Syafii, N. I., Chen, Y., Hajadi, N., Sathyanarayanan, H. \& Manickavasagam, Y. V. (2011). Evaluation of the impact of the surrounding urban morphology on building energy consumption. Solar Energy, 85 (1), 57-71. doi: 10.1016/j.solener.2010.11.002

Zhou, Y., Zhuang, Z., Yang, F., Yu, Y. \& Xie, X. (2017). Urban morphology on heat island and building energy consumption. Procedia Engineering, 205, 2401-2406. doi: 10.1016/j.proeng.2017.09.862

\section{UKŁAD URBANISTYCZNY A OSZCZĘDNOŚĆ ENERGII}

\section{STRESZCZENIE}

W dobie zmian klimatycznych jednym z najważniejszych wyzwań projektowania architektonicznego jest ograniczenie zużycia energii w budynkach do celów ogrzewania i chłodzenia. Znaczącym składnikiem bilansu energetycznego budynków są pasywne zyski słoneczne, których wielkość zależy między innymi od wzajemnego położenia budynków. Artykuł omawia wstępne badania nad możliwościami osiągnięcia oszczędności energii w budynkach na etapie projektowania urbanistycznego w polskich realiach prawnych i klimatycznych. Badania obejmują analizę kilku wariantów układu budynków dla tej samej lokalizacji.

Słowa kluczowe: urbanistyka, architektura energooszczędna, nasłonecznienie, układ budynków 